\title{
Factor Analysis on Criteria Affecting Lean Retrofit for Energy Efficient Initiatives in Higher Learning Institution Buildings
}

\author{
Nur IzieAdiana Abidin ${ }^{1, *}$, Rozana Zakaria $^{1}$, Eeydzah Aminuddin ${ }^{1}$, Abdul Rahim Abdul \\ Hamid $^{1}$,Vikneswaran Munikanan ${ }^{2}$, Shaza Rina Sahamir ${ }^{3}$ and Siti Mazzuana Shamsuddin ${ }^{4}$ \\ ${ }^{1}$ Faculty of Civil Engineering, Universiti Teknologi Malaysia, Johor Bahru, Malaysia \\ ${ }^{2}$ Faculty of Engineering, Universiti Pertahanan Malaysia, Kuala Lumpur, Malaysia \\ ${ }^{3,4}$ Faculty of Architecture, Planning and Surveying, Universiti Teknologi Mara, Shah Alam, Selangor, \\ Malaysia
}

\begin{abstract}
The expansion of Higher Learning Institution (HLI) is a global concerns on energy demand due to campus act like a small city. Intensive mode of operation of a building is correlated to the energy utilization. Improvement in the current energy efficiency is crucial effort to minimize the environmental effect through minimisation of energy in operation by retrofitting and upgrade the existing building system or components to be more efficient. Basically, there are three recommended steps for the improvement known as lean initiatives, green technology and clean energy in response to becoming zero energy solutions for building. The deliberation of this paper is aimed to highlight the criteria affecting in retrofitting of existing building in HLI with lean initiatives in order to achieve energy efficiency and reduction of energy comsumption. Attention is devoted to reviewing the lean energy retrofitting initiatives criteria for daylighting (side lighting), daylighting (skylight) and glazing. The questionnaire survey was employed and distributed to the architects who has an expertise in green building design. Factor analysis was adopted as a method of analysis by using Principal Component with Varimax Rotation. The result is presented through summarizing the sub-criteria according to its importance with a factor loading 0.50 and above. The result found that majority of the criteria developed achieved the significant factor loading value and in accordance with the protocal of analysis. In conclusion the results from analysis of this paper assists the stakeholders in assessing the significant criteria based on the desired lean energy retrofitting initiatives and also provides a huge contribution for future planning improvement in existing buildings to become an energy efficient building.
\end{abstract}

* Corresponding author: rozana@utm.my 


\section{Introduction}

The critical issue in campus buildings is often associated with the energy efficiency and it indirectly gives an impact to the occupant's comfort and indoor quality [1]. Campus universities have been called as small cities since it has large size, large users and involved with complex activities. The wastage of energy in campus comes from various spaces such as lecture halls, offices, computer rooms, laboratories, street lighting and others. Their activities and operations from the teaching, research, and other services affects the building energy use and to the environment. However, the energy and environmental impact in campus universities able to be reduced with several approaches through technology, organizational and energy optimization initiative [2]. According to [3], the effective implementation to improve the current energy condition and at the same time concern to achieve for sustainability in existing building is through the adoption of energy efficiency. This shall be implemented by replacing the existing mechanical and electrical technology and building system with more energy efficient application which beneficial in reducing the expenditure of energy. [4] stated that, the basic principle with the implementation of energy efficiency is to reduce the operations of energy which including lighting, heating and cooling without denying the comfort and health of users in the space. In addition, the improvement of energy efficiency not only beneficial for environmental protection, but also to the economic especially the operational cost savings. Besides, [5] argued that in order to achieve a great reduction of energy usage, the effective decision in energy plan and management and the technical measures should be under consideration.

\section{Literature Review}

\subsection{Retrofitting in Higher Learning Institution}

Retrofitting known as the process to add the existing building systems with new technology, services or functions. The changes are commonly implemented in the structure of interior space in a building which is constructed whether wholly or partially occupied [6]. Basically, the campus energy demand and its building performance are influences from several sources of its existing components or systems such as lighting, building envelope and mechanical system. The improvement for lighting system is the most simple retrofit initiative that could be implemented through integration with daylighting, occupancy sensor installation, convert the existing lighting system with high performance and high lighting efficacy. While higher consideration in building envelope, it able to improve through painting, insulation, shading and glazing system. Meanwhile, for the mechanical system which known as high energy consumers in a building could reduce the usage by adopting the natural ventilation, replace the existing window and installing the variable frequency drives [5].

Table 1 shows the critical summary of energy efficiency initiatives that is commonly implemented in campus building. It consists of several initiatives from lean energy, green technology and clean energy. For the lean energy, the initiative that has been successfully and effectively applied consists of wall, window, roof/atrium and daylighting. Therefore, in order to fulfil the aim of this paper, this information, it assists in finding the lean energy initiatives which are relevant to implement on campus. 
Table 1. Summary of Energy Efficiency Initiatives Taken in Campuses [12]

\begin{tabular}{|c|c|c|c|c|c|c|c|c|c|}
\hline Retrofit Initiatives & 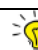 & (8) & (6) & & 田 & 6 & n & & \\
\hline a) Indiana State University [7] & & & & & & & $\sqrt{ }$ & & \\
\hline b) University of Malaya [8] & $\sqrt{ }$ & & & & & & & & \\
\hline c) U.S colleges [9] & $\sqrt{ }$ & & & & & $\sqrt{ }$ & $\sqrt{ }$ & & \\
\hline d) College of Desert [10] & $\sqrt{ }$ & $\sqrt{ }$ & & & & & & & \\
\hline e) Boston University [11] & $\sqrt{ }$ & & & & & $\sqrt{ }$ & & $\sqrt{ }$ & \\
\hline f) Rome Italy University Building [12] & $\sqrt{ }$ & & & & $\sqrt{ }$ & & $\sqrt{ }$ & $\sqrt{ }$ & \\
\hline g) UC Berkeley's University [13] & & $\sqrt{ }$ & & & & & & & \\
\hline h) University of Mexico [14] & $\sqrt{ }$ & & $\sqrt{ }$ & & & & & & $\sqrt{ }$ \\
\hline i) Melbourne University [15] & $\sqrt{ }$ & & & & & & & & \\
\hline j) University of Seoul Korea [16] & $\sqrt{ }$ & $\sqrt{ }$ & & $\sqrt{ }$ & $\sqrt{ }$ & & $\sqrt{ }$ & & \\
\hline k) Curtin University Sarawak [17] & $\sqrt{ }$ & $\sqrt{ }$ & & & & & & & \\
\hline l) Guangdong Colleges [18] & $\sqrt{ }$ & $\sqrt{ }$ & & & & $\sqrt{ }$ & & & \\
\hline m) Kingsville Texas University [19] & $\sqrt{ }$ & $\sqrt{ }$ & & & & & & & \\
\hline n) University of Malaya [20] & & $\sqrt{ }$ & & & & & & & \\
\hline
\end{tabular}

Legend:

\begin{tabular}{|l|l|l|}
\hline Lighting & Solar & Window \\
\hline Ventilation & R Rofflatrium & Occupancy sensor \\
\hline Refrigeration & S Wall & Daylight \\
\hline
\end{tabular}

\subsection{Retrofitting Technology}

According to [21], there are three steps recommended to be adopted towards the achievement of sustainable building. Firstly, is the utilization of natural resources which known as lean energy, secondly is to take into account on the green technology and lastly is to utilized for clean energy which is the opportunity to have the clean sources towards in achieving zero energy building. The detail explanation of the three steps is discussed in the section below.

\subsubsection{Lean Energy, Green Technology and Clean Energy}

Lean energy (passive design) is defined as the principals of design that concern with current innovations of technology [21]. The important implementation of lean energy is to less utilize the energy and practice to become energy efficient to reduce the existing demand [22]. The levels of efficiency and cost involve in passive design is different based on the techniques adopted. Therefore, the techniques selected prior to implementation should take into account the function of the building, expected thermal comfort, loss, and gain of energy in the building, potential energy saving, weather, location and environment [23]. Passive design is the strategy that offers an economical and effective approach. Buildings with passive design able to achieve savings over $50 \%$ of the total primary energy consumption [24]. There are several passive technologies that could be applied in a building. Firstly, external shading technology is effective to reduce the air-conditioning usage by preventing sunlight admitted into the building during summer but allow it to enter during winter. Secondly, is the natural light utilization by concerning on the window wall ratio at certain orientations in order to reduce the electric light consumption. Thirdly is green roof technology which able to significantly improve the building temperature [25]. 
Green technology is described as an adoption of technologies that is low carbon as an effort to supply the energy efficiently [21]. Green technology is also an innovation of technology which is developed to protect the environment and reduce the energy by utilizing new technology at the existing electricity equipment [26]. Besides, green technology is to develop and apply systems, equipment and product which has a large contribution to the environment and to conserve the natural resource in order to minimize the impacts from the activities which carried out by humans [27]. It is said that passive technology known as preferred approach and active technology is complementary in green building design, however, it is actually balancing many of the needs to extra indoor performance comfort to a building [25].

Clean energy is the renewable technologies that can be applied as an opportunity to achieve for greater reduction of energy [21]. Clean energy is the renewable energy sources such as wind power, solar photovoltaics and solar hot water which capable to meet the energy demand in the building. Since most of the countries in this global using fossil fuels to generate the electricity and thus indirectly has contributed to the large emission of greenhouse gases and the atmosphere becoming warm. With the clean sources such as wind, sun and water alternative, it provides a large reduction of greenhouse gas emission [28]. Besides, [29] also mentioned that, clean energy approach is the great solution in reducing the greenhouse gas emission because it is capable to minimize the $\mathrm{CO}_{2}$ emissions which generated from the fossil fuel carbon oxidation.

\section{Method}

In this paper, lean energy (Passive Design) is only deliberated in its survey and analysis. A questionnaire survey approach was adopted to elicit the important criteria affecting in retrofitting for lean energy that consists of daylighting (side lighting), daylighting (skylight) and glazing. Each of the lean energy retrofitting initiatives has been developed with its own criteria and it is specifically required the respondents to give the degree of importance of each criteria based on the scale given. The establishment of criteria is by reviewing in detail the available information from secondary data such as books, published journal, thesis and online articles. In order to obtain the information pertaining on the criteria affecting in retrofitting of lean energy, a total of 392 questionnaires was sent to the Architects whereby the selections is based on the applicability and reliability of respondents as a designer towards the green building design for HLI. From the total of sample distributed, 85 has successfully returned and response which indicate the response rate of $33.46 \%$.

Then, Factor Analysis was adopted to prioritized and ranked the criteria. Factor Analysis known as a data reduction method by collapsing a large number of variables into several underlying factors and allow to make an arrangement according to its significant value [30].

In order to perform this statistical analysis, the Statistical Package for Social Science (SPSS) was used with the adoption of several protocols. Firstly, assess the Kaiser-MeyerOlkin (KMO) whereby the requirement for the minimum value is 0.50 . Secondly, is Barlett's Test of Sphericity $(P)$ with the minimum value is $P<0.50$ [31]. Thirdly is to focus on the factor of extraction for which Principal Component Analysis has been selected and it is the default setting of the software. Then, Varimax with orthogonal rotation were chosen as the rotational method. Lastly is the factor loading value with the aim in retaining the factor 0.50 and above. The result obtained were arrange based on the value of importance of the criteria. 


\section{Findings}

\subsection{Daylighting (sidelighting)}

Daylighting is the passive approach that uses solar energy as the main resources to utilize the natural light in the interior space of a building [32]. Daylighting has become a preferred application in most of architecture design since it offers for uniformity with its illumination distribution and also has the potential to reduce the energy by $20 \%$ [33]. In addition, natural light provides the users to have a pleasant environment, comfortability, improves the productivity in comparing to artificial lighting [34]. In daylighting, there are 39 variables were loaded in Factor Analysis that subjected to Principal Component Analysis. From Table 2, Kaiser-Meyer-Olkin(KMO) achieved is 0.872 which shows the adequacy of sampling since it exceeds the recommended value of 0.50 , and the Barlett's Test of Sphericity is $(P=.000)$ which indicated as statistical significance.

Table 2. Kaiser-Meyer-Olkin and Barlett's Test of Sphericity for Daylighting (Side Lighting)

\begin{tabular}{|l|l|r|}
\hline \multicolumn{2}{|c|}{ KMO and Bartlett's Test } \\
\hline Kaiser-Meyer-Olkin Measure of Sampling Adequacy. & .872 \\
\hline Bartlett's Test of Sphericity & Approx. Chi-Square & 2791.614 \\
\cline { 2 - 3 } & df & 741 \\
\cline { 2 - 3 } & Sig. & .000 \\
\hline
\end{tabular}

Then, the Varimax rotation was conducted to retain the factor and to interpret the components into simple structure solution. From 39 variables, 36 variables have achieved the factor loading 0.50 and above. The result as shown in Table 3.

Table 3. Kaiser-Meyer-Olkin and Barlett's Test of Sphericity for (Daylighting-skylights)

\begin{tabular}{|c|l|c|}
\hline Main Criteria & \multicolumn{1}{|c|}{ Sub-criteria } & Factor loading \\
\hline \multirow{4}{*}{ Visual Comfort } & Cleaning & 0.797 \\
\cline { 2 - 3 } & Painting & 0.770 \\
\cline { 2 - 3 } & Analyze placement and configuration & 0.752 \\
\cline { 2 - 3 } & Locate windows high in a wall & 0.662 \\
\cline { 2 - 3 } & Avoid direct beam & 0.655 \\
\hline Indoor Quality & Thermal comfort & 0.586 \\
\cline { 2 - 3 } & Impact on cooling requirement & 0.559 \\
\hline \multirow{5}{*}{ Design } & Window shape & 0.829 \\
\cline { 2 - 3 } & Size of room & 0.748 \\
\cline { 2 - 3 } & Daylight redirecting system & 0.708 \\
\cline { 2 - 3 } & Interior design and space planning & 0.687 \\
\cline { 2 - 3 } & Incorporated interior and exterior & 0.658 \\
\hline \multirow{3}{*}{$\begin{array}{c}\text { Environmental } \\
\text { Assessment }\end{array}$} & ghading & 0.834 \\
\cline { 2 - 3 } & Mreenhouse gas emission & 0.834 \\
\cline { 2 - 3 } & Return on investment & 0.791 \\
\cline { 2 - 3 } & Construction Costs & 0.622 \\
\cline { 2 - 3 } & Simple payback & 0.636 \\
\hline \multirow{2}{*}{$\begin{array}{c}\text { Resource } \\
\text { Availability }\end{array}$} & Sun patterns and condition & 0.701 \\
\cline { 2 - 3 } & & \\
\cline { 2 - 3 } & Solar geometry and effective sky angle & 0.503 \\
\hline
\end{tabular}




\subsection{Daylighting (Skylight)}

Skylight is another method to utilize for natural light and being a new trend in modern design architecture especially for commercial building development [35]. Skylight able to improve the quality of lighting in the workspace, improve productivity, space has a variation of appearance and reduce the need of electric lighting during the daytime [36].

The protocol performed in this section is similar from the previous section. For skylights, the sampling adequacy of Kaiser-Meyer-Olkin(KMO) is 0.892 and the statistical significant of Bartlett's Test Sphericity is $(P=.000)$. The result as shown in Table 4.

Table 4. Kaiser-Meyer-Olkin and Barlett's Test of Sphericity for (Daylighting-skylights)

\begin{tabular}{|l|l|r|}
\hline \multicolumn{2}{|c|}{ KMO and Bartlett's Test } \\
\hline Kaiser-Meyer-Olkin Measure of Sampling Adequacy. & .892 \\
\hline Bartlett's Test of Sphericity & Approx. Chi-Square & 1446.224 \\
\cline { 2 - 3 } & df & 253 \\
\cline { 2 - 3 } & Sig. & .000 \\
\hline
\end{tabular}

Meanwhile, Table 5 shows the summary result achieved after performing the Varimax rotation which contains of factor loading 0.50 and above. It is arranged based on the sequence from most important to least important which performed under 6 main criteria.

Table 5. Summary Result for Daylighting (Daylighting-Skylights)

\begin{tabular}{|c|l|c|}
\hline Main Criteria & \multicolumn{1}{|c|}{ Sub-criteria } & Factor loading \\
\hline \multirow{4}{*}{ Design } & Integrate with electric lighting system & 0.842 \\
\cline { 2 - 3 } & $\begin{array}{l}\text { Aim for recommended surface reflectance } \\
\text { value }\end{array}$ & 0.782 \\
\cline { 2 - 3 } & Size and shapes of roof lights & 0.743 \\
\cline { 2 - 3 } & Determine the daylight factor & 0.704 \\
\cline { 2 - 3 } & Building Massing and orientation & 0.649 \\
\hline \multirow{2}{*}{ Resource Availability } & Solar geometry and sky angle & 0.679 \\
\cline { 2 - 3 } & Sun patterns and condition & 0.586 \\
\hline \multirow{2}{*}{ Indoor Comfort } & Impact on cooling requirement & 0.869 \\
\cline { 2 - 3 } & Thermal comfort & 0.803 \\
\hline \multirow{2}{*}{ Economic Assessment } & Maintenance and repair cost & 0.807 \\
\cline { 2 - 3 } & Construction cost & 0.783 \\
\cline { 2 - 3 } & Return on investment & 0.730 \\
\cline { 2 - 3 } & Simple payback & 0.697 \\
\cline { 2 - 3 } & Energy and cost savings & 0.563 \\
\hline Environmental & Greenhouse gas emission & 0.780 \\
\hline Visual Comfort & Painting & 0.533 \\
\cline { 2 - 3 } & Provision for regularly cleaning & 0.513 \\
\hline
\end{tabular}

\subsection{Glazing}

In most of commercial building development, glazing has been widely adopted and become the statement in architectural design. Glazing provides the occupants in a building to harvest the daylight, view to the outside environment and indoor quality [37]. Since window allows to receive for fresh air and connect the occupants to the views outside, it is also easily caused to heat gain and heat loss which then contributed to the building heating and cooling loads. Thus, glazing is the efficient initiative that could be adopted in reducing the energy cost and at the same time ensuring for comfortability, clean and healthier environment [38]. 
For glazing lean retrofit initiative, there are 32 variables loaded which also performed under Principal Component Analysis. The result from sampling adequacy assessment revealed has exceeded the recommended which is 0.865 . Whilst, Bartlett's Test of Sphericity also revealed for statistical significant with $(P=.000)$. Both of the results can be seen in Table 6.

Table 6. Kaiser-Meyer-Olkin and Barlett's Test of Sphericity (Glazing)

\begin{tabular}{|l|l|r|}
\hline \multicolumn{2}{|c|}{ KMO and Bartlett's Test } \\
\hline Kaiser-Meyer-Olkin Measure of Sampling Adequacy. & .865 \\
\hline Bartlett's Test of Sphericity & Approx. Chi-Square & 2119.956 \\
\cline { 2 - 3 } & df & 496 \\
\cline { 2 - 3 } & Sig. & .000 \\
\hline
\end{tabular}

Then, based on the Varimax rotation, there are 3 variables require to be eliminated from 32 variables loaded since the factor loading less than 0.50 . The summary result of strong factor loading of 0.50 and above is tabulated in Table 7.

Table 7. Summary Result for Glazing

\begin{tabular}{|c|c|c|}
\hline Main Criteria & Sub-criteria & Factor loading \\
\hline \multirow{14}{*}{ Glazing Selection } & Glazing shape & 0.845 \\
\hline & Type of insulation & 0.834 \\
\hline & $\begin{array}{l}\text { Frame types, styles, finishes, colour and } \\
\text { durability }\end{array}$ & 0.759 \\
\hline & U-value of glazing properties & 0.752 \\
\hline & Visible transmittance and Visible reflectance & 0.734 \\
\hline & Spectral Selectivity & 0.733 \\
\hline & Glazing sizes & 0.725 \\
\hline & Glazing colours & 0.717 \\
\hline & Types of glazing & 0.708 \\
\hline & $\begin{array}{l}\text { Solar heat gain coefficient and Shading } \\
\text { Coefficient }\end{array}$ & 0.686 \\
\hline & Ultraviolet Transmittance & 0.581 \\
\hline & Sound Transmittance & 0.574 \\
\hline & Durability & 0.569 \\
\hline & Good safety features & 0.564 \\
\hline \multirow{4}{*}{ Design } & Ability to comply with technical standards & 0.664 \\
\hline & Determine the desired light levels & 0.551 \\
\hline & Aesthetic / glass appearance & 0.638 \\
\hline & Determine the orientation of glazing & 0.574 \\
\hline \multirow[t]{3}{*}{ Occupants Comfort } & Health and Indoor air quality & 0.797 \\
\hline & Thermal comfort & 0.741 \\
\hline & Glare control & 0.739 \\
\hline \multirow{5}{*}{ Economic Assessment } & Maintenance Costs & 0.758 \\
\hline & Energy and cost saving & 0.726 \\
\hline & Construction costs & 0.679 \\
\hline & Payback Period & 0.652 \\
\hline & Return on investment & 0.612 \\
\hline \multirow[t]{2}{*}{ Site Assessment } & Determine the angle incidence of solar & 0.588 \\
\hline & Climate conditions in the location & 0.504 \\
\hline Environmental & Greenhouse gas emission & 0.541 \\
\hline
\end{tabular}




\section{Conclusion}

Retrofitting has gained placed by many universities since the government started to promote the effort for sustainability campus due to the realization of rising global energy demands. The campus university building also has always been targeted and being the transformation centers in order to overcome the energy issue for the benefits of current and future generations. Lean energy is an energy efficient initiative that able to significantly contribute to the energy reduction in campus through the utilization of the innovative approach. It is the first step that is recommended to be adopted in order to achieve the aim for sustainable building. Therefore, the development of the lean energy criteria in this paper assists in providing the stakeholders with the information that require being considered during the decision of the retrofit project selected especially in planning and design stage. There are 28 main criteria that consist of visual comfort, indoor quality, design, environmental, economic and others. The findings from Factor Analysis have shown the significant of the criteria based on its factor loading value which provides as a reliable guide for the prioritization process.

\section{References}

1. Jomoah, I. M., \& Arabia, S. Energy Management in the Buildings of a University Campus in Saudi Arabia - A Case Study. International Conference on Power Engineering, Energy and Electrical Devices. 13-17 (2013).

2. Kolokotsa, D., Gobakis, K., Papantoniou, S., Georgatou, C., Kampelis, N., Kalaitzakis, K.,Santamouris, M. Development of a web based energy management system for University Campuses: The CAMP-IT platform. Energy and Buildings, 123, 119-135 (2016).

3. Tan B., Yavuz Y., Otay E.N., Çamlıbel E. Optimal Selection of Energy Efficiency Measures for Energy Sustainability of Existing Buildings, Computers \& Operations Research, 66, 258-271. (2016).

4. Ruparathna, R., Hewage, K., and Sadiq, R. Improving The Energy Efficiency Of The Existing Building Stock: A Critical Review Of Commercial And Institutional Buildings. Renewable and Sustainable Energy Reviews, 53, 1032-1045. (2016).

5. Alshuwaikhat, H,M., \& Abubakar, I. An Integrated Approach to Achieving Campus Sustainability: Assessment of the Current Campus Environmental Management Practices. Journal of Cleaner Production. 16, 1777-1785 (2008).

6. Eriksson, R., Nenonen, S., Junghans, A., Nielsen, S. B., \& Lindahl, G. Nordic Campus Retrofitting Concepts Scalable Practices. Procedia Economics and Finance, 21(15), 329-336 (2015).

7. Appleby P. Sustainable Retrofit and Facilities Management. $1^{\text {st }}$ edition. Oxford, United Kingdom. Routledge (2013).

8. Mahlia T.M.I., Razak H.A., Nursahida M.A. Life cycle Cost Analysis and Payback Period of Lighting Retrofit at the University of Malaya, Renewable and Sustainable Energy Reviews, 15 (2), 1125-113 (2011).

9. National Grid. Managing Energy Costs in Colleges and Universities. Street Boulder Colorodo: E Source Companies LLC (2003).

10. College of Desert. College of the Desert Campus-wide Lighting Retrofit. Southern California: Edison International (2011). 
11. Gevelber M., Choate R., Sheehan K., Vitolo T., Ercolino E., Ricci L., Mchale M. Opportunities for Achieving Significant Energy Reduction in Existing University Buildings: Developing efficient HVAC operations. Boston United States: Boston University (2007).

12. Citterio M., Romeo C. Retrofit of a University Building in Rome Italy. Energy Conservation in Buildings and Community System Case Study Overview. Rome Italy: International Energy Agency. (2003).

13. UC Berkeleys., 2012, UC Berkeley's University Hall Wireless HVAC Retrofit Brings the Campus One Step Closer to Its Climate Neutrality, Energy Technology Assistance Program, California, USA.

14. Escobedo A., Briceño S., Juárez H., Castillo D., Imaz M.,Sheinbaum C. Energy Consumption and GHG Emission Scenarios of A University Campus in Mexico Energy for Sustainable Development, 18(1), 49-57 (2014).

15. Di Stefano J. Energy Efficiency and The Environment: The Potential for Energy Efficient Lighting to Save Energy and Reduce Carbon Dioxide Emissions at Melbourne University, Energy, 25(9), 823-839 (2000).

16. Chung M.H., Rhee E.K. Potential Opportunities for Energy Conservation in Existing Buildings on University Campus: A field survey in Korea. Energy and Buildings, 78, 176-182 (2014).

17. Tang F.E. An Energy Consumption Study for a Malaysian, International Journal of Environment, Earth Science and Engineering, 8, 99-105 (2012).

18. Zhou, X., Yan, J., Zhu, J., \& Cai, P. Survey Of Energy Consumption and Energy Conservation Measures for Colleges and Universities In Guangdong Province, Energy and Buildings, 66, 112-118 (2013).

19. Ayala E., Kocurek J., Wright J., Sijansky L., Chang J., Jr Contreras R. C. Energy Efficient Method Identification for an Education Building, Architectural EngineeringConference 2011, California United States. 235-243 (2011).

20. Saidur R., Hasanuzzaman M., Mahlia T.M.I., Rahim N.A., Mohammed H.A. Chillers Energy Consumption, Energy Savings and Emission Analysis in an Institutional Buildings, Energy, 36(8), 5233-5238 (2011).

21. Chee Yue, J.L OTTV Calculation and Energy Simulation Technique for GreenRE Rating System. Integrated Environmental Solutions (2014).

22. Tymkow,P., Tassou,S., Kolokotroni,M., Jounara,H. Building Services Design for Energy Efficient Buildings. USA: Routledge (2008).

23. Goudarzi, H., and Mostafaeipour, A. Energy Saving Evaluation of Passive Systems for Residential Buildings in Hot and Dry Regions. Renewable and Sustainable Energy Reviews, 68, 432-446 (2017).

24. Gong, X., Akashi, Y., and Sumiyoshi, D. Optimization of passive design measures for Residential Buildings in Different Chinese Areas. Building and Environment, 58, 4657 (2012).

25. Ma, S. L., Ding, Y., Shen, R. J., and Zhu, N. A Case Study of an Optimization Retrofit of the Heat Supply System in a Campus of Tianjin. Applied Mechanics and Materials, 170-173, 2670-2674 (2012).

26. Puvanasvaran,A.P., Yop Zain, M.F., Al-Hayali,Z.A., Mukapit,M. Sustainability of Green Technology in Malaysia Industry. International Conference on Design and Concurrent Engineering. Universiti Teknikal Melaka (2012). 
27. Hassan, F. Application of Green Technology in Malaysia Construction: Have We Got It Right? International Construction Week \& Ecobuild SEA 2014. Kuala Lumpur (2014).

28. Danby, D., Menter, A., and Faludi, J. Passive Design Strategies. Retrieved From:http://sustainabilityworkshop.autodesk.com/buildings/passive-design-Strategies (2011).

29. Wu, M. H., Ng, T. S., and Skitmore, M. R. Sustainable Building Envelope Design by Considering Energy Cost and Occupant Satisfaction. Energy for Sustainable Development. 31, 118-129 (2016).

30. Pallant,J. (2014). Spss Survival Manual. A step by Step Guide to Data Analysis Using SPSS for Windows (Version 12). ( $1^{\text {st }}$ edi). New South Wales: Allen and Unwin.

31. Williams B., Brown T. and Onsman. Exploratory Factor Analysis: A five-step guide for novices, Australasian Journal of Paramedicine, 8(3) (2012).

32. Syed Fadzil S.F., Byrd H., Energy and Building Control Systems in the Tropics, $1^{\text {st }}$ edition, Universiti Sains Malaysia Pulau Pinang, Malaysia (2012).

33. Zain-Ahmed, A., Sopian, K., Othman, M. Y. H., Sayigh, A. A M., and Surendran, P. N. Daylighting as a Passive Solar Design Strategy in Tropical Buildings: A Case Study of Malaysia. Energy Conversion and Management, 43, 1725-1736 (2002).

34. Lu, J., Birru, D., and Whitehouse, K. Using Simple Light Sensors to Achieve Smart Daylight Harvesting. Proceedings of the 2nd ACM Workshop on Embedded Sensing Systems for Energy-Efficiency in Building - BuildSys',10, 73 (2010).

35. Calcagni, B., and Paroncini, M. Daylight Factor Prediction in Atria Building Designs. Solar Energy, 76(6), 669-682 (2004).

36. Manglani, P., Mchugh, J., Heschong, L., Dee, R., and Group, H. M. Modular Skylight Systems : Best Practices for Designing Skylights with Suspended Ceilings Potential for Skylight Systems with Suspended Ceilings. 214-225 (2004).

37. Selkowitz, S., \& Lee, E. Integrating Automated Shading and Smart Glazings with Daylight Controls. International Symposium on Daylighting Buildings, 10 (2004).

38. Lyons, P., Hockings, B., Reardon, C., Reidy, C., and GramlickHamber, R. Your Home: Australia's Guide to Environmentally Sustainable Homes- Glazing. (5th ed). Australian Government Department of Industry-Glazing (2013). 